Used in the Analysis of a Power and Control System during the Second Industrial Revolution. Sport, Education and Society, Taylor Francis (Routledge). June 21, Vol. 7 (1). Pp. 5-23.

9. Hardman K. et al. (2014) World-wide survey of school physical education: final Report. Paris, France: UNESCO. $131 \mathrm{p}$.

10. Sami R. Yli-Piipari (2015) Physical Education Curriculum Reform in Finland. Quest. October. 35 p. DOI: $10.1080 / 00336297.2014 .948688$

11. Cooper KH, Greenberg JD, Castelli D.M, Barton M, Martin SB, Morrow Jr. JR. (2016) Implementing Policies to Enhance Physical Education and Physical Activity in Schools. Research Quarterly for Exercise and Sport. Vol. 87 (2). Pp. 133-140. URL: http://dx.doi.org/10.1080/02701367.2016.1164009

\begin{tabular}{|c|c|}
\hline \multicolumn{2}{|c|}{ Цитування на цю статтю: } \\
\hline \multicolumn{2}{|c|}{$\begin{array}{l}\text { Яковенко АВ. Сучасний стан фізичного виховання школярів у європейських країнах. Вісник Прикар- } \\
\text { патського університету. Серія: Фізична культура. } 2019 \text { Берез 26; 33: 125-132 }\end{array}$} \\
\hline Відомості про автора: & Information about the author: \\
\hline $\begin{array}{l}\text { Яковенко Артем Володимирович - старший ви- } \\
\text { кладач, Придніпровська державна академія фізич- } \\
\text { ної культури і спорту (Дніпро, Україна) }\end{array}$ & $\begin{array}{l}\text { Yakovenko Artem Volodymyrovych - lecturer, Pry- } \\
\text { dniprovska State Academy of Physical Culture and } \\
\text { Sports (Dnipro, Ukraina) }\end{array}$ \\
\hline $\begin{array}{l}\text { e-mail: yakovenkoartem2012@ gmail.com } \\
\text { https://orcid.org/0000-0003-0338-8437 }\end{array}$ & \\
\hline
\end{tabular}

\author{
УДК 338.48-2-057.875 \\ doi: 10.15330/fcult.33.132-141
}

Maksym Yachnyuk, Sevil Chubatenko, Emil Ibragimov

\title{
ANALYSIS OF STUDENTS' PRIORITY MOTIVES IN THE INDUSTRY OF ACTIVE TOURISM
}

Встановлено, щчо мотивачій до занять туризмом є багато, але лише деякі з них вагомими $i$ такими, щзо можуть впливати на результат прийняття рішення. Щоб з ясувати мотивацію студентів у сфері туризму та відпочинку, необхідно встановити мотиви, якими молодь керується у своӥх діях. Процес дослідження вимагав використання системного аналізу, соціологічних, педагогічних $i$ математичних методів. Опитування дало нам змогу встановити як молодь проводить своє дозвілля; виявити фактори, які змушують студентів бути активними; встановити причини, які змушують студентів зайнятися обраною рекреаційною діяльністю; а також причини, щзо їм заважають та очікуваний ефект від такої діяльності. Проведене анкетування засвідчило, щуо студенти бажають активно відпочивати, мають мотиваџійне ціннісне ставлення до занять активним туризмом $і$ рекреаційною діяльністю.

Ключові слова: молодь, мотивація, рекреаційна активність, активне дозвілля.

Any activity proceeds from biological needs formed in the process of human being 's interaction with the environment. The study of students' of higher educational establishments motivation to participation in programs of recreational activity is an essential condition to help develop effective steps for the rise of students' motion behavior, said steps be based on the principles of the priority of needs, motives and interests of individuals One of the main factors of choice travel decision is motivation. It is found that there are a lot of tourist's motivations, but only some of them are weighty and can influence the decision outcome. To find out the students motivation in tourism and recreation there must be installed the motives, which guide young people in their actions. The study process has required the use of system analysis, sociological, pedagogical and mathematical statistics methods. The questioning aimed at establishment of how the youth spends its leisure time; disclosure of factors that make students be active in recreation; finding the reasons that make students be engaged in chosen recreation/health-improving activity, as well as of reasons that prevent them from said activity; and the effect expected by students from such activity. It is proved that the motivational sphere always consists of a number of motives, ideals and values, needs, motivations, goals, interests, etc. The conducted questionnaires of students shows that students want to relax actively, have motivational value attitude to employment tourism and recreational activities. The students' leisure time 
depends, on the one hand, on demographic factors and social-cultural environment, on the other - it is connected with the system of their values, needs and interests.

Key words: young people, motivations, recreational activity, active leisure.

Introduction. Any activity proceeds from biological needs formed in the process of human being's interaction with environment. However, the problem itself rejects the character of subject's activity, since can be satisfied in different ways and with different subjects, while the subject of satisfaction is defined at the time when the human started to act.

To thoroughly clarify students' motivation in the active tourism sphere and, as certain, the ways of its formation, one needs to know the top priorities guided them in their wishes to take a part in the process of educational and extracurricular activity [2].

The study of students' of higher educational institutions motivation to participation in programs of recreational activity is an essential condition to help to develop effective steps for the rise of students' motion behavior, said steps be based on the principles of the priority of needs, motives and interests of individuals [1, 3].

Materials and methods. The process of study has required the use of the system analysis, sociological, pedagogical and mathematical statistics methods. To learn the students' recreational activity and active tourism motivations, we have conducted the survey, where 330 students of Chernivtsi Yuriy Fedkovych National University have been questioned.

Results and discussion. The survey showed that the majority of students $(48,5 \%)$ were only partially satisfied with organization of recreation/health-improving activity in this educational institution; nearly one third $(30,3 \%)$ were fine with it, and $21,2 \%$ were not satisfied at all. To respondents' opinion, such situation refers to a number of reasons as: nonconsideration of students' interests in motion activity events conduction held by university as extracurricular activities; episodic nature of recreational events; insufficiency of recreation activity experts with innovational technologies knowledge for such activities' organization; absence of appropriate facilities and resources for recreation events conduction; authoritative approach to recreation measures planning; insufficient level of systematic recreation awareness activity; commercialization of recreation activity and its subsequent inaccessibility to different students categories; non-consideration of factors that form the structure of students' leisure time.

Studying the students' attitude towards recreation/health-improving activity, we have established that $12,0 \%$ of female and $18,4 \%$ of male students never took part in recreation measures; the one third of female $(30,6 \%)$ and far less male students $(17,5 \%)$ did take part; and the majority of female $(70,5 \%)$ and precisely the half of male students participated in recreation measures from time to time.

The majority of young people $(80,3 \%)$ stated that recreation/health-improving exercises had improved their health, and $49,1 \%$ told they had raised their psychical equilibrium. Physical efficiency improving from recreation/health-improving activity was stated by $41,5 \%$ of the respondents, while the quarter of them $(24,8 \%)$ regarded the exercises to be efficient to normalize their body weight. It was with $20,0 \%$ of students that the rise of mental efficiency was emphasized, while the same of self-esteem was mentioned in $14,2 \%$ out of all cases. The insignificant number of respondents $(1,5 \%)$ stated that the efficiency from recreation/healthimproving activity was other than the above [4].

The results of our sociological study have disclosed major motives guiding students, when they decide to go in for recreation and health promotion. It should be first noted that the motion activity is of the prior significance in a complex scope of factors that effect on young man's/lady's state of health and working capacity. The latest national studies also prove certain correlation between the motion activity and health state. It was established that the 
health-improving motives (health state improvement: $70,5 \%$ with female, and 73,3\% with male students) were predominant in the hierarchy of recreation/health-improving motives.

We have established that the interests guiding young people during their student's life have the form of desire to have a better health and a good psycho-emotional state; a significant number of students believed that they have already reached a certain selfexpression level and were sufficiently physically capable. The questioning was also helpful in disclosure of reasons that prevent students from engagement in recreation/health-improving activity.

Thus, the lack of time has shown to be the most weighty reason that prevented both female and male students from being engaged in recreation and health improvement $(59,7 \%$ and $50,9 \%$ correspondingly), which, in its turn, is connected with huge academic load $(52,5 \%$ and $40,3 \%$ ).

Unavailability of recreation/health-improvement groups was mentioned by $16,9 \%$ of females and $24,5 \%$ of males. The lack of money to pay for activity was an essential obstacle to $15,4 \%$ of females and $13,6 \%$ of males (see fig. 1 ).

It was also a worth-noting moment that the students of both sexes mentioned they had a lack of knowledge for recreation and health-improvement activity conduction, as well as did not have friends with whom they were likely to engage themselves in such activity.

Further analysis of questioning has confirmed our assumption that the students were not aware of educational work significance with respect to efficient use of their leisure time.

It seemed important to know what forms of recreation/health-improving activity were most frequently chosen by the students, and it appeared that the majority of the respondents preferred exercises in groups (62,3\% female, 68,0\% male students), which can be explained by the students' gravitation towards the company, social life and experience exchange. The questioned students emphasized that they preferred the group exercises form instead of individual, and this fact seems to be helpful in future recreation activity organization and planning. As to individual and independent recreation activity, it was chosen by practically the same number of male and female respondents [4].

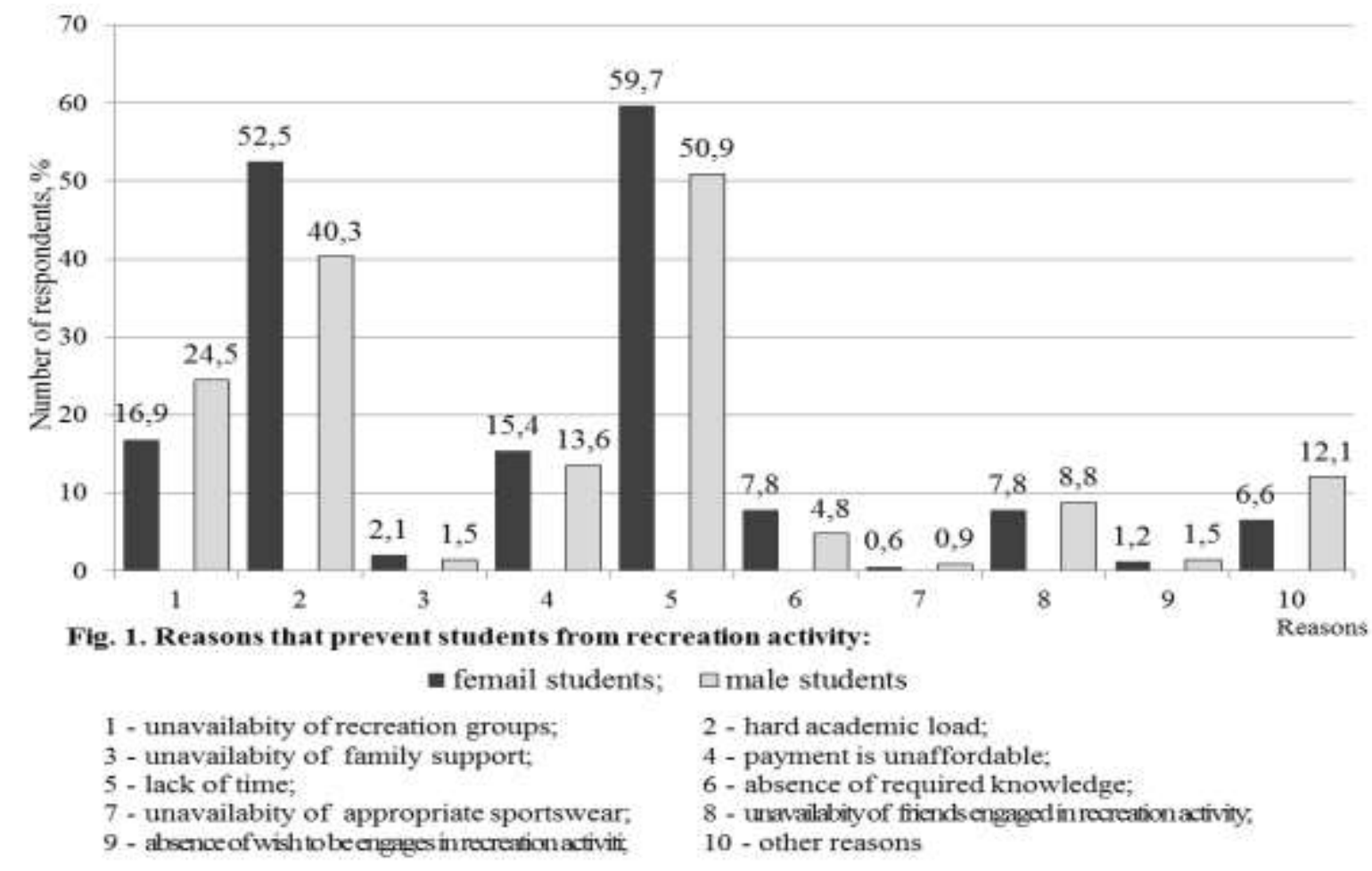


Recreation/health-improving activity can be conducted practically everywhere. As the survey results showed, the majority of the respondents would prefer the outdoors recreation/health-improving activity (52,5\% female and 51,0\% male students), or such activity conducted in physical culture centers (51,4\% female, $47,6 \%$ male students) (fig. 2 ).

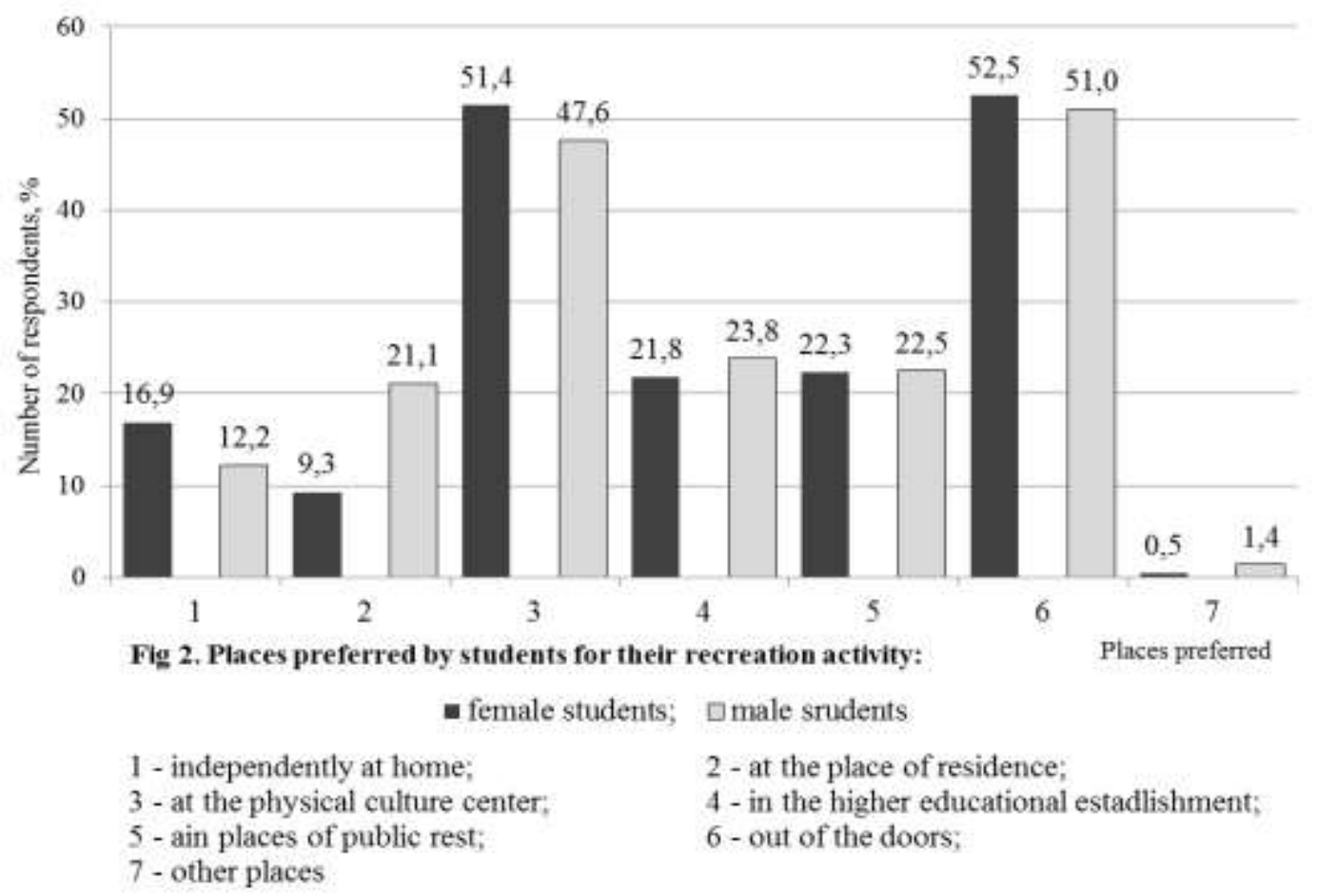

The questioning has confirmed the trends disclosed in special literature with respect to regularities in the conduction place choice of recreation/health-improving activity. To respondents' opinion, the outdoors exercises had higher health improving effect; they were multivarious, more interesting and raised the psycho-emotional state at the expense of physical exercises and natural factors combined effect.

It should be noted that the structure of leisure time interests in female and male students had its special particularities. It was established that the female students preferred to spend their leisure time in such forms as walking $(61,7 \%)$, watching video or TV set $(53,6 \%)$, reading $(49,7 \%)$, listening music $(48,1 \%)$, and visiting their relatives $(47,5 \%)$. Male students mostly spent their leisure time doing physical exercises $(46,3 \%)$, walking or watching video $(42,9 \%)$, helping the family at home $(41,5 \%)$ and playing computer games $(38,1 \%)$.

The youth's leisure time was incidental to contradictory trends: some of students' leisure-time activities were of positive focus and led to cultural advance, the other contained negative potentiality and resulted in poor and monotonous pastime.

We accent on significant percentage of both female and male students who choose passive rest (watching TV was chosen by $53,6 \%$ of female and $42,9 \%$ of male students; reading books and periodicals was peculiar with $49,7 \%$ of female and $19,0 \%$ of male students; computer games and communication via social media was preferred by $20,8 \%$ of females and $38,1 \%$ of males, etc). A youth's radical internet activity involvement is observed as the reason of leisure-time activity general decline. The internet activity is perhaps the most popular pastime. The deficit of face-to-face contacts is compensated by virtual communication which, on students' opinion, allows to solve problems that can not be solved in real social medium. The passive leisure time almost excludes elements that provide for necessary and sufficient physical and psychological renewal levels, especially recreation and health-improving focus. 


\section{Conclusions}

Active tourism means inculcation into students' leisure activity contributed essentially into students' physical state increase. The above results allow to recommend this approach for students' leisure activity organization.

Future investigation trends are connected with an effect of tourism means inculcation into student's leisure activity technology on students' physical and psycho-emotional state. The students' leisure time depends, on the one hand, on demographic factors and social-cultural environment, on the other - it is connected with the system of their values, needs and interests.

The development of students' focus on complex forms of society's cultural potential is undoubtedly among the most important tasks of the higher school.

\section{References}

1. Zakharina YeA. Specificities of Students' Motivation to Health-Preserving Activities. Scientific journal of the National Pedagogical Dragomanov University. Series № 15. Scientific and pedagogical problems of physical culture (physical culture and sports). 2015; 3(56): 164-67.

2. Prystupa YeN, Zhdanova OM, Lynets MM, editors. Physical Recreation: A manual for Students of Higher Educational Establishments for Physical Culture and Sports. Lviv:Lviv state University of Physical Culture; 2010. 447 p.

3. Yurchyshyn YuV. The State and Specificities of Students' Motivation to Motion Activity of HealthImproving Directionality on Present-Day Stage of Realization of Physical Education in Higher Educational Establishments. Pedagog. psychol. med.-biol. probl. phys. train. sports. 2012; 4: 118-23.

4. Yachnyuk MYu. Students' Motivation to Tourism Activity. Slobozhanskyi herald of science and sport. 2012; 5(2): 143-45.

\section{Цитування на цю статтю:}

Yachnyuk MY, Chubatenko SY, Ibragimov TY. Analysis of students' priority motives in the industry of active tourism. Вісник Прикарпатського університету. Серія: Фізична культура. 2019 Берез 26; 33: 132-136

\begin{tabular}{|c|c|}
\hline Відомості про автора: & Information about the author: \\
\hline $\begin{array}{l}\text { Ячнюк Макисм Юрійович - кандидат наук з фі- } \\
\text { зичного виховання і спорту, Чернівецький націо- } \\
\text { нальний університет імені Юрія Федьковича } \\
\text { (Чернівці, Україна) }\end{array}$ & $\begin{array}{l}\text { Yachniuk Makysm Yuriiovych - Candidate of Science } \\
\text { (Physical Education and Sport), Yuriy Fedkovych } \\
\text { Chernivtsi National University (Chernivtsi, Ukraina) }\end{array}$ \\
\hline \multicolumn{2}{|l|}{$\begin{array}{l}\text { e-mail: m.yachnyk @ chnu.edu.ua } \\
\text { https://orcid.org/0000-0001-7653-2802 }\end{array}$} \\
\hline $\begin{array}{l}\text { Iбрасімов Еміль Юсирович - викладач, Буковин- } \\
\text { ський державний медичний університет (Чернівці, } \\
\text { Україна) }\end{array}$ & $\begin{array}{l}\text { Ibrahimov Emil Yusyrovych - lecturer, Bukovinian } \\
\text { State Medical University (Chernivtsi, Ukraina) }\end{array}$ \\
\hline $\begin{array}{l}\text { Чубатенко Сівіль Юсирівна - старший викладач, } \\
\text { Буковинський державний медичний університет } \\
\text { (Чернівці, Україна) }\end{array}$ & $\begin{array}{l}\text { Chubatenko Sivil Yusyrivna - lecturer, Bukovinian } \\
\text { State Medical University (Chernivtsi, Ukraina) }\end{array}$ \\
\hline
\end{tabular}

УДК 615.8

doi: 10.15330/fcult.33.136-141

Роксолана Горбата

\section{ЕФЕКТИВНІСТЬ ЗАСТОСУВАННЯ ДИХАННЯ ЗА БУТЕЙКОМ У КОМПЛЕКСНІЙ ПРОГРАМІ ФІЗИЧНОЇ ТЕРАПІЇ ПАЦІЕНТІВ ІЗ ХРОНІЧНИМ ОБСТРУКТИВНИМ ЗАХВОРЮВАННЯМ ЛЕГЕНЬ}

Мета: оцінити ефективність застосування дихання за Бутейком у комплексній програмі фізичної терапії пацієнтів із хронічним обструктивним захворюванням легень. Методи. У прочесі виконання дослідження були застосовані аналіз літератури, фізіологічні методи (проведення проб із затримкою дихання (Штанге, Генча), оцінка вираженості задишки за икалою Борга, визначення тяжкості задишки за шкалою Флетчера,оцінка функиіонального стану пачієнтів на основі результатів 